\title{
TINJAUAN PENGETAHUAN DAN PENDIDIKAN IBU RUMAH TANGGA DALAM RANGKA PENCEGAHAN PENYAKIT KULIT DI DESA MEE TEUNGOH KECAMATAN MUTIARA BARAT KABUPATEN PIDIE TAHUN 2018
}

\author{
Review of Knowledge and Education of Household Mother in The Order of Skin Disease \\ Prevention in Teungoh Mee Village, West Mutiara Sub-District, Pidie District, 2018

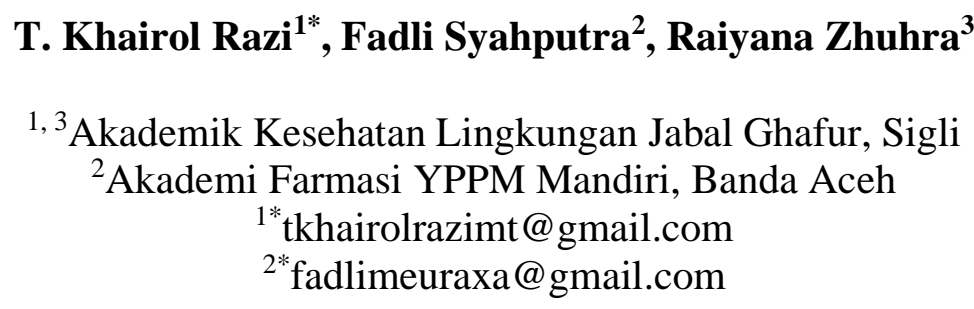

\begin{abstract}
ABSTRAK
Latar Belakang: Penyakit kulit merupakan kelainan kulit yang diakibatkan oleh adanya jamur, kuman-kuman, parasit, virus maupun infeksi. Penyakit kulit adalah penyakit infeksi yang paling umum, terjadi pada orang-orang dari segala usia. Sebagian besar pengobatan infeksi kulit membutuhkan waktu lama untuk menunjukkan efek. Masalahnya menjadi lebih mencemaskan jika penyakit tidak merespon terhadap pengobatan. Metode: Penelitian ini bersifat Deskriptif yaitu dengan desain crossectional yaitu melihat Pengetahuan dan Pendidikan Ibu rumah Tangga Dalam Rangka Pencegahan Penyakit Kulit di Desa Mee Teungoh Kecamatan Mutiara Barat Kabupaten Pidie. Populasi dalam penelitian ini adalah seluruh masyarakat penderita penyakit kulit di desa Mee Teungoh Kecamatan Mutiara Barat Kabupaten Pidie yaitu sebanyak 34 orang. Hasil: Berdasarkan hasil penelitian tentang pengetahuan dan pendidikan ibu rumah tangga dalam rangka pencegahan penyakit kulit didesa Mee Tengoh Kecamatan Mutiara Barat Kabupaten Pidie tahun 2018 dapat diambil kesimpulan sebagai berikut: Dari 34 responden yang dilakukan penelitian diketahui bahwa responden yang berpendidikan tinggi sebanyak 3 orang $(8,8 \%)$ dan responden yang berpendidikan menegah sebanyak 11 orang $(32,4 \%)$ sedangkan responden yang berpendidikan dasar sebanyak 20 orang (58,5\%). Dari 34 responden yang dilakukan penelitian diketahui bahwa responden yang berpengetahuan baik sebanyak 32 orang $(94,1 \%)$ dan berpengetahuan rendah sebanyak 2 orang $(5,9 \%)$. Saran: Diharapkan penderita penyakit kulit agar mandi sehari dua kali dan menganti pakaian yang bersih, serta diharapkan kepada petugas puskesmas agar memberikan penyuluhan mengenai faktor-faktor yang mempengaruhi terjadinya penyakit kulit.
\end{abstract}

Kata Kunci: Pengetahuan, Pendidikan, Penyakit Kulit

\section{ABSTRACT}

Background: Skin disease is a skin disorder caused by fungi, germs, parasites, viruses or infections. Skin disease is the most common infectious disease, affecting people of all ages. Most skin infection treatments take a long time to show an effect. The problem becomes more worrisome if the disease does not respond to treatment. Methods: This research is descriptive with a cross- 
Jurnal Sains Riset (JSR)

p-ISSN 2088-0952, e-ISSN 2714-531X

http://journal.unigha.ac.id/index.php/JSR

DOI. 10.47647/jsr.v10i12

sectional design, namely looking at the knowledge and education of housewives in the context of preventing skin diseases in Mee Teungoh Village, Mutiara Barat District, Pidie Regency. The population in this study were all people with skin diseases in Mee Teungoh Village, Mutiara Barat District, Pidie Regency, as many as 34 people. Results: Based on the results of research on the knowledge and education of housewives in the context of preventing skin diseases in Mee Tengoh village, Mutiara Barat District, Pidie Regency in 2018, the following conclusions can be drawn: From 34 respondents who conducted the study, it was found that 3 people with highly educated education \%) and respondents with secondary education were 11 people (32.4\%) while respondents with basic education were 20 people (58.5\%). Of the 34 respondents who conducted the study, it was found that 32 respondents with good knowledge (94.1\%) and low knowledge were 2 people (5.9\%). Suggestion: It is hoped that sufferers of skin diseases should bathe twice a day and change clean clothes, and it is hoped that the health center staff will provide information about the factors that influence the occurrence of skin diseases.

Keywords: Knowledge, Education, Skin Diseases

\section{PENDAHULUAN}

Menurut Menteri Kesehatan RI, dr. Nafisah Mboi, Sp.A, MPH dalam sambutannya pada Rapat Kerja Kesehatan Nasional (Rakernas) Regional Barat tahun 2013, pencapaian MDGs bidang kesehatan sampai saat ini belum mencapai target. Akan tetapi, menurut melalui Ringkasan Peta Jalan Pencapaian Percepatan Tujuan Pembangunan Milenium di Indonesia yang dikeluarkan Kemenkes RI ada 5 target Millenium Development Goals/MDGs yang menunjukkan kemajuan signifikan, beberapa di antaranya yaitu prevalensi balita kekurangan gizi yang berkurang dari 31 persen pada tahun 1989 menjadi 18,4 pada tahun 2007. Sedangkan target 2015 sebesar 15,5 persen dan angka kematian balita telah menurun dari 97 per 1000 kelahiran pada tahun 1991 menjadi 44 per 1000 kelahiran pada tahun 2007 dan diperkirakan target 32 per 1000 kelahiran pada tahun 2018 akan tercapai (Depkes RI, 2013).

Sudah selayaknya Millenium Development Goals/MDGs ini bisa menjadi tanggung jawab bersama untuk pencapaian bersama di 2015. Tugas berat tidak hanya dititikberatkan pada pemerintah semata. Namun juga dititikberatkan kepada pelayan kesehatan dan orang-orang berintelektual yang turut serta membangun Indonesia dengan intelektual. Target Millenium Development Goals/MDGs dapat dikatakan dapat kita capai dengan mudah asalkan semua lini ikut serta dalam pencapaian target tersebut yang nantinya manfaatnya akan kita rasakan untuk semua kalangan. Menyuarakan target MDGs kepada semua lapisan masyarakat harus dilakukan lebih gencar lagi agar mencapai keberhasilan dari target-target yang dicanangkan. Indonesia sehat yang berintelektual melalui MDGs akan sangat mudah kita capai di 2018 nanti (Depkes RI, 2013).

Delapan tujuan MDGs yang harus dilaksanakan oleh setiap negara yang mendeklarasikannya yaitu; 1) menanggulangi kemiskinan dan kelaparan,2) mencapai pendidikan dasar untuk semua, 3) mendorong kesetaraan genderdan pemberdayaan perempuan, 4) menurunkan angka kematian anak, 5) meningkatkan kesehatan ibu, 6) memerangi HIV/AIDS, malaria dan penyakit menular lainnya, 7) memastikan kelestarian lingkungan hidup, dan 8) mengembangkan kemitraan global untuk pembangunan. Indonesia sebagai salah satu negara yang ikut dalam mendeglarasikan tujuan MDGs memiliki kewajiban untuk melaksanakan upaya untuk mencapai target MDGs dan memonitor perkembangan kemajuan pencapaian, salah satunya yaitu 
penangulanggan penyakit terutama penyakit kulit (UNDP, 2008).

Penyakit kulit merupakan kelainan kulit yang diakibatkan oleh adanya jamur, kuman-kuman, parasit, virus maupun infeksi. Penyakit kulit adalah penyakit infeksi yang paling umum, terjadi pada orang-orang dari segala usia. Sebagian besar pengobatan infeksi kulit membutuhkan waktu lama untuk menunjukkan efek. Masalahnya menjadi lebih mencemaskan jika penyakit tidak merespon terhadap pengobatan. (Anjar, 2009).

Berdasarkan hasil penelitian sebelumnya yang dilakukan Panjaitan (2008) menunjukkan penyakit kulit yang menjadi dominan terjadi di Kabupaten Waringin Timur dengan prevalensi 2,45 \% dari populasi di dua Kecamatan, namun di beberapa desa dengan tingkat sosial ekonomi yang rendah menunjukkan prevalensi penyakit kulit jauh lebih tinggi yaitu berkisar $17 \% 20 \%$. Hal yang berbeda diungkapkan dalam hasil penelitian $\mathrm{K}$ et al (2012) di Ahmedabad yang memperlihatkan bahwa pada umumnya paling banyak kejadian penyakit yang diakibatkan oleh jamur dengan insidensi sebesar 52,78\% (Panjaitan, 2008).

Pada 1999, insidensi penyakit kulit di dunia diperkirakan 640.000. Pada 2000, 738.284 kasus ditemukan. Pada 1999, 108 kasus terjadi di Amerika Serikat sedangkan $70 \%$ kasus dunia terdapat di India, Myanmar, dan Nepal. Pada 2002, 763.917 kasus ditemukan di seluruh dunia, dan menurut WHO pada tahun itu, $90 \%$ kasus penyakit kulit dunia terdapat di Brasil, Madagaskar, Mozambik, Tanzania dan Nepal (Depkes RI, 2005).

Diantara 122 negara yang endemis pada tahun 1985, 98 negara telah mencapai eliminasi penyakit kulit yaitu prevalensi rate < 1/10.000 penduduk. Pada tahun 1991, World Health Assembly telah mengeluarkan suatu resolusi yaitu eliminasi penyakit kulit tahun 2000. Pada 1999, insidensi penyakit kulit di dunia diperkirakan 640.000 dan 108 kasus terjadi di Amerika Serikat. Pada 2000, Word Health Organisation membuat daftar 91 negara yang endemik. $70 \%$ kasus dunia terdapat di India, Myanmar, dan Nepal (Depkes RI, 2005).

Pada tahun 2011 Indonesia menempati urutan ke tiga setelah India dan Brazil dalam hal penyumbang jumlah penderita penyakit kulit di dunia. Walaupun ada penurunan yang cukup drastis dari jumlah kasus terdaftar, namun sesungguhnya jumlah penemuan kasus baru tidak berkurang sama sekali. Oleh karena itu, selain angka prevalensi rate, angka penemuan kasus baru juga merupakan indikator yang harus diperhatikan (Depkes RI, 2011).

Pada pertengahan tahun 2011, Indonesia telah mencapai eliminasi sesuai target WHO. Pada tahun 2011, distribusi penyakit kulit menurut waktu yaitu pada akhir tahun Desember 2011 sebanyak 18.312 penderita yang terdiri dari $2.814 \mathrm{~PB}$ dan $15.498 \mathrm{MB}$ dengan prevalens rate 0,86 per 10.000 penduduk terdapat di 10 provinsi, yaitu: Jawa Timur, Jawa Barat, Sulawesi Selatan, Papua, NAD, DKI Jakarta, Sulawesi Utara, Maluku Utara, dan Nusa Tenggara Timur (Depkes RI, 2011).

Berdasarkan data yang di peroleh dari puskesmas mutiara Barat diketahui bahwa penderita penyakit kulit karena jamur karena alergi sebanyak 941 kasus dan penyakit kulit akibat jamur sebanyak 651 sedangkan penyakit kulit akibat infeksi sebanyak 612 kasus di wilayah kerja puskesmas mutiara barat. Sedangkan jumlah penderita penyakit kulit di Desa Mee Teungoh sebanyak 34 orang (Puskesmas Mutiara Barat, 2017).

Berdasarkan latar belakang diatas maka penulis berkeinginan untuk melakukan penelitian mengenai Tinjauan Pengetahuan dan Pendidikan Ibu Rumah Tangga dalam Rangka Pencegahan Penyakit Kulit di Desa Mee Teungoh Kecamatan Mutiara Barat Kabupaten Pidie Tahun 2018. 


\section{METODOLOGI PENELITIAN}

Penelitian ini bersifat Deskriptif yaitu dengan desain crossectional yaitu melihat Pengetahuan dan Pendidikan Ibu rumah Tangga dalam Rangka Pencegahan Penyakit Kulit di Desa Mee Teungoh Kecamatan Mutiara Barat Kabupaten Pidie Tahun 2018.

Populasi dalam penelitian ini adalah seluruh masyarakat penderita penyakit kulit di desa Mee Teungoh Kecamatan Mutiara Barat Kabupaten Pidie yaitu sebanyak 34 orang. Sedangkan sampel dalam penelitian ini adalah keseluruhan populasi yang ada (total populasi. Hal ini sejalan dengan pendapat Arikunto (2006), apabila populasi kurang dari pada 100, maka sebaiknya semua jumlah populasi di jadikan sampel penelitian. Adapun sampel dalam penelitian ini sebanyak 34 orang.

Metode pengumpulan data yaitu menggunakan observasi dan wawancara langsung dengan menggunakan fomulir yang sudah baku yaitu kuesioner. Data yang diperoleh akan di olah secara manual dan melakukan rekapitulasi data agar memudahkan untuk tahapan selanjutnya.

Analisis data dilakukan secara deskriptif, maka dalam analisanya tidak menggunakan uji statistik, tapi hanya berdasarkan pada tabel distribusi frekuensi, dan tabulasi silang. Serta penyajian data dilakukan dalam bentuk tabel distribusi frekuensi dan tabulasi silang berserta narasi tabel.

\section{HASIL PENELITIAN}

Tabel 1. Analisis Univariat Distribusi Pendidikan dan Pengetahuan Ibu Rumah Tangga dalam Rangka Pencegahan Penyakit

Kulit di Desa Mee Teungoh Kecamatan Mutiara Barat Kabupaten Pidie Tahun 2018

\begin{tabular}{lcc}
\hline \multirow{2}{*}{ Variabel } & \multicolumn{2}{c}{ Jumlah } \\
\cline { 2 - 3 } & N & \% \\
\hline \hline Pendidikan Ibu Rumah Tangga & & \\
\hline Dasar & 20 & 58,8 \\
Menengah & 11 & 32,4 \\
Tinggi & 3 & 8,8 \\
\hline
\end{tabular}

Pengetahuan Ibu Rumah

Tangga

\begin{tabular}{|c|c|c|c|}
\hline \multirow[t]{2}{*}{1.} & $\begin{array}{l}\text { Pengertian penyakit kulit } \\
\text { Ta }\end{array}$ & Pengertian penyakit kulit & 52,9 \\
\hline & Tidak tau & 16 & 47,1 \\
\hline \multirow[t]{3}{*}{2.} & Cara mandi yang benar & & \\
\hline & Tau & 34 & 100 \\
\hline & Tidak tau & - & - \\
\hline \multirow[t]{3}{*}{3.} & Penyebab penyakit kulit & & \\
\hline & Tau & 29 & 85,3 \\
\hline & Tidak tau & 5 & 14,7 \\
\hline \multirow[t]{3}{*}{4.} & \multicolumn{3}{|c|}{ Cara pencegahan penularan penyakit kulit } \\
\hline & Tau & 34 & 100 \\
\hline & Tidak tau & . & - \\
\hline \multirow[t]{3}{*}{5.} & \multicolumn{3}{|c|}{ Cara mencuci tangan yang benar } \\
\hline & $\mathrm{Ta}$ & 32 & 94,1 \\
\hline & Tidak tau & 2 & 5,9 \\
\hline \multirow[t]{3}{*}{6.} & $\begin{array}{l}\text { Cara menjaga kebersihan } \\
\text { kuku }\end{array}$ & & \\
\hline & Tau & 15 & 44,1 \\
\hline & Tidak tau & 19 & 55,9 \\
\hline \multirow[t]{3}{*}{7.} & $\begin{array}{l}\text { Menjaga } \\
\text { pakaian }\end{array}$ & & \\
\hline & $\mathrm{Ta}$ & 34 & 100 \\
\hline & Tidak tau & - & - \\
\hline \multirow[t]{3}{*}{8.} & Memakai handuk sendiri & & \\
\hline & Tau & 33 & 97,1 \\
\hline & Tidak tau & 1 & 2,9 \\
\hline \multirow[t]{3}{*}{9.} & $\begin{array}{l}\text { Cara penggunaan handuk } \\
\text { yang benar }\end{array}$ & & \\
\hline & Tau & 28 & 82,4 \\
\hline & Tidak tau & 6 & 17,6 \\
\hline \multirow[t]{4}{*}{$\begin{array}{c}10 \\
\cdot\end{array}$} & $\begin{array}{l}\text { Mengganti sprei } \\
\text { benar }\end{array}$ & & \\
\hline & 2 minggu sekali & 23 & 67,6 \\
\hline & Lebih dari 2 minggu sekali & 11 & 32,4 \\
\hline & Jumlah & 34 & 100 \\
\hline
\end{tabular}

\section{PEMBAHASAN}

Pendidikan

Berdasarkan hasil penelitian pada 34 responden diketahui bahwa pendidikan responden yang tergolong tinggi sebanyak 3 orang $(8,8 \%)$ dan responden yang berpendidikan menegah sebanyak 11 orang $(32,4 \%)$ sedangkan responden yang berpendidikan dasar sebanyak 20 orang $(58,5 \%)$. Penelitian ini sejalan dengan penelitian Ika Sri Lulestri (2014) bahwa terdapat hubungan antara pendidikan ibu rumah tangga dengan kejadian penyakit kulit (2014). 
Peneliti berasumsi bahwa ada hubungan tingkat pendidikan dengan kejadian penyakit kulit, yaitu semakin tinggi tingkat pendidikan seeorang maka cenderung semakin banyak pengetahuan dan pengalaman yang di perolehnya sehingga semakin tinggi pula dukungannya terhadap lingkungan khusunya terhadap pencegahan dan cara menghindari penyakit kulit.

Adapun tingkat pendidikan Responden di Desa Mee Tengoh banyak tamatan SD dan SMA sehingga pengetahuan tentang pencegahan penyakit kulit masih banyak responden tidak mengerti dan paham dikarenakan kurangnya pendidikan, hanya beberapa orang yang tau dan mengerti tentang cara pencegahan penyakit kulit.

\section{Pengetahuan}

Berdasarkan hasil penelitian pada 34 responden diketahui bahwa Pengetahuan masyarakat yang tergolong baik sebanyak 32 orang $(94,1 \%)$ sedangkan pengetahuan yang kurang sebanyak 2 orang (5,9\%). Apabila pengetahuan responden baik maka semakin baik pula cara pencegahan penyakit kulit, begitu pula sebaliknya apabila tingkat pengetahuan rendah maka resiko terkena penyakit kulit semakin besar kemungkinannya.

Adapun cara untuk mencegah terjadinya penyakit kulit ialah seperti ; tingkatkan kebersihan diri, tingkatkan kekebalan tubuh dengan cara banyak mengkonsumsi makanan bergizi (multivitamin) dan istirahat yang cukup., hindari kontak langsung dengan penderita, bila bersinggungan/bersentuhan dengan penderita segera cuci tangan, hindari penggunaan perlengkapan pribadi secara bersamaan (selimut, pakaian, handuk, sabun mandi, dll) dan lakukan perawatan dan pengobatan pada anggota keluarga yang menderita penyakit kulit yang cenderung menular.

Sebaiknya agar tidak terjadinya penularan atau terjadinya penyakit kulit anggota keluarga tidak bertukar-tukar handuk dan pakaian, dan sebaiknya saat mandi mengunakan sabun dan mandi sehari 2 kali yaitu pagi dan sore hari agar terhindar dari penyakit kulit yang di sebabkan oleh jamur. Tujuan mandi adalah untuk menjaga kebersihan tubuh, mengurangi infeksi akibat kulit kotor, memperlancar sistem peredaran darah, dan menambah kenyamanan seseorang. Mandi dapat menghilangkan mikroorganisme dari kulit serta sekresi tubuh, menghilangkan bau tidak enak, memperbaiki sirkulasi darah ke kulit, dan membuat seseorang merasa rileks dan segar.

\section{KESIMPULAN DAN SARAN Kesimpulan}

Berdasarkan hasil penelitian tentang pengetahuan dan pendidikan ibu rumah tangga dalam rangka pencegahan penyakit kulit didesa Mee Tengoh Kecamatan Mutiara Barat Kabupaten Pidie tahun 2018 dapat diambil kesimpulan sebagai berikut :

1. Dari 34 responden yang dilakukan penelitian diketahui bahwa responden yang berpendidikan tinggi sebanyak 3 orang $(8,8 \%)$ dan responden yang berpendidikan menegah sebanyak 11 orang $(32,4 \%)$ sedangkan responden yang berpendidikan dasar sebanyak 20 orang $(58,5 \%)$.

2. Dari 34 responden yang dilakukan penelitian diketahui bahwa responden yang berpengetahuan baik sebanyak 32 orang $(94,1 \%)$ dan berpengetahuan rendah sebanyak 2 orang $(5,9 \%)$.

\section{Saran}

1. Diharapkan penderita penyakit kulit agar tidak bertukar-tukar handuk dengan anggota keluarga lain nya.

2. Diharapkan penderita penyakit kulit agar mandi sehari dua kali dan menganti pakaian yang bersih.

3. Diharapkan kepada petugas puskesmas agar memberikan penyuluhan mengenai faktor-faktor yang mempengaruhi terjadinya penyakit kulit. 
Jurnal Sains Riset (JSR)

p-ISSN 2088-0952, e-ISSN 2714-531X

http://journal.unigha.ac.id/index.php/JSR

DOI. $10.47647 /$ jsr.v10i12

4. Diharapkan kepada masyarakat kondisi rumah tidak lembab.

5. Diharapkan kepada penderita penyakit kulit agar mandi memakai sabun.

\section{DAFTAR PUSTAKA}

1. Chandra, 2006, Konsep dan Penerapan Metodelogi Penelitian Kepeawatan. Selemba Medika, Jakarta.

2. Dwi, 2008, Kesehatan Anak Untuk Perawat, Petugas Penyuluhan Kesehatan dan Bidan di Desa, Gadjah Mada University Press. Jogjakarta.

3. Faulkner, 2008, Pengantar Epidemologi Penyakit Menular, Rineka Cipta, Jakarta.

4. http://www.who.int/topics/millenium_d evelopment_goals/about/en/index.html

5. http://www.depkes.go.id/index.php/berit a/press-release/2240-kebijakankementerian-kesehatan-dalammencapai-mdgs.html

6. http://mdgsindonesia.org/official/index. $\mathrm{php} /$ component/content/article/20Materi\%20MDGs/51

7. http://www.menkokesra.go.id/content/m enko-kesra-perbaikan-gizi-kuncipenekan-angka-kematian-bayi

8. Notoatmodjo, S. 1997. Ilmu Kesehatan Masyarakat Prinsip-Prinsip Dasar. P.T. Rineka Cipta : Jakarta

9. Notoatmodjo, S. 2003. Pendidikan Dan Perilaku Kesehatan. P.T. Rinneka Cipta: Jakarta

10. Notoatmodjo,S.,2007. Promosi Kesehatan dan Ilmu Perilaku Kesehatan, Teori dan Aplikasi . P.T. Rineka Cipta : Jakarta.

11. Poter, Perry. dalam Depdikbud. Hubungan Tingkat Pengetahuan Ibu Pemulung tentang Personal Hygiene dengan Kejadian Skabies pada Balita di Tempat Pembuangan Akhir Kota Semarang. Jurnal. Dinamika Kebidanan Vol. 1 No. 1. Diakses pada tanggal 1 Maret 2013.

12. Peraturan Menteri Tenaga Kerja Dan Transmigrasi Nomor 7 Tahun 2014 tentang Upah Minimum.

13. Sander, 2005. Anjar, 2009, Suriah, Indra Fajarwati Ibnu Bagian Promosi Kesehatan dan Ilmu Perilaku, Fakultas Kesehatan Masyarakat, Unhas, Makassar.

14. UNDP, 2008 Indicators table 2008, Human Development Indices http://hdr.Undp. org/en/ Statistics/data/hdi/2008. 